\title{
Moscovian (Carboniferous) microfossils (Bryozoa, Conodonta, and Fusulinida) from Novaya Zemlya, Arctic U.S.S.R.
}

\author{
HANS A. NAKREM, INGER NILSSON, and BJØRN T. SIMONSEN
}

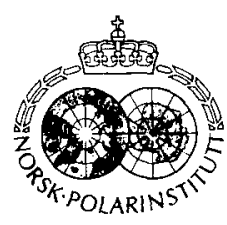

\begin{abstract}
Nakrem, H. A., Nilsson, I., \& Simonsen, B. T. 1991: Moscovian (Carboniferous) microfossils (Bryozoa, Conodonta, and Fusulinida) from Novaya Zemlya, Arctic U.S.S.R. Polar Research 9(1), 45-64.

A considerable amount of geological material collected during a Norwegian expedition, led by Olaf Holtedahl, to Novaya Zemlya in 1921 has been re-examined in light of geological activities in the Barents Shelf area. Parts of the collections were described between 1924 and 1930, but the present work contains the first illustrated descriptions of Carboniferous bryozoans, conodonts and fusulinids from Novaya Zemlya. A total of 15 fusulinid taxa are identified, including the stratigraphically important species Pseudostaffella gorskyi (Dutkevich), P. paracompressa Safonova, Neostaffella cf. greenlandica (Ross and Dunbar), $N$. sphaeroidea (Ehrenberg), Profusulinella prisca (Deprat) and $P$. priscoidea Rauzer-Chernousova. A few conodonts were extracted and assigned to Idiognathodus cf. delicatus Gunnell, Streptognathodus cf. parvus Dunn, and Declinognathodus cf. noduliferus (Ellison and Graves). Four bryozoan taxa are described, including Prismopora holtedahli $\mathrm{n} . \mathrm{sp}$., a new species of the order Cystoporata. These faunas are similar to those from the latest Bashkirian and Moscovian of the Russian Platform, Svalbard, the Sverdrup Basin, and North America. The age of the investigated material is early Moscovian (Vereiskian to Kashirskian) according to the standard Russian scheme.
\end{abstract}

Hans A. Nakrem and Bjørn T. Simonsen*, Paleontological Museum, Sars gate 1, N.0562 Oslo 5, Norway; Inger Nilsson, Continental Shelf and Petroleum Technology Research Institute Ltd. (IKU), N-7034 Trondheim, Norway.

The objectives of the 1921 Norwegian Novaya Zemlya Expedition, led by Professor Olaf Holtedahl, were to explore the geology, as well as the living plant and animal life, of Novaya Zemlya. During the 10 weeks of the expedition, from June to August 1921, Holtedahl and his crew collected a wealth of information which resulted in 40 scientific reports (Holtedahl 1922, 1924, 1930; Fredericks 1927) and numerous shorter papers. Using the vessel "Blaafjeld", the expedition team sailed through the Matochkin Strait as far north as Arkhangel Bay (Fig. 1). Large and varied paleontological collections were made from the Cambrian to Cretaceous strata. The entire collection is housed in the Paleonotological Museum in Oslo and has recently been catalogued (Nakrem 1989). Almost 4000 specimens are available for further investigations. Previously described material, including figured fossil types, comprises 290 specimens.

* Present address: Norsk Hydro A/S (Avd. T3-5), P.O. Box 4313, N-5013 Nygårdstangen, Norway.

\section{Investigated material}

The carboniferous succession of Novaya Zemlya comprises fossiliferous shales, marls and limestones with rich fauna dominated by brachiopods and corals. During the middle Carboniferous period, the southern seaway to the Tethys faunal province was still open, and light-coloured limestones were formed under tropical conditions (see Heafford (1988) for further palaeogeographic discussion). Three samples have been investigated: two from Cape Productus [Cape Borisoff], $7 \mathrm{~km}$ north of Mashigin Fiord, and one from the Eastern Krestovii Island (between Arkhangel Bay and Pankratyeff Peninsula) (see Fig. 1). It has not been possible to obtain a detailed measured section at either of these two localities, but Fig. 2 shows the lithological section at Cape Productus reconstructed after Holtedahl's publications and after discussions with Dr. V. Matweew and Dr. N. N. Sobolev, Leningrad.

All types and illustrated specimens are housed in the collection of the Paleontological Museum, 


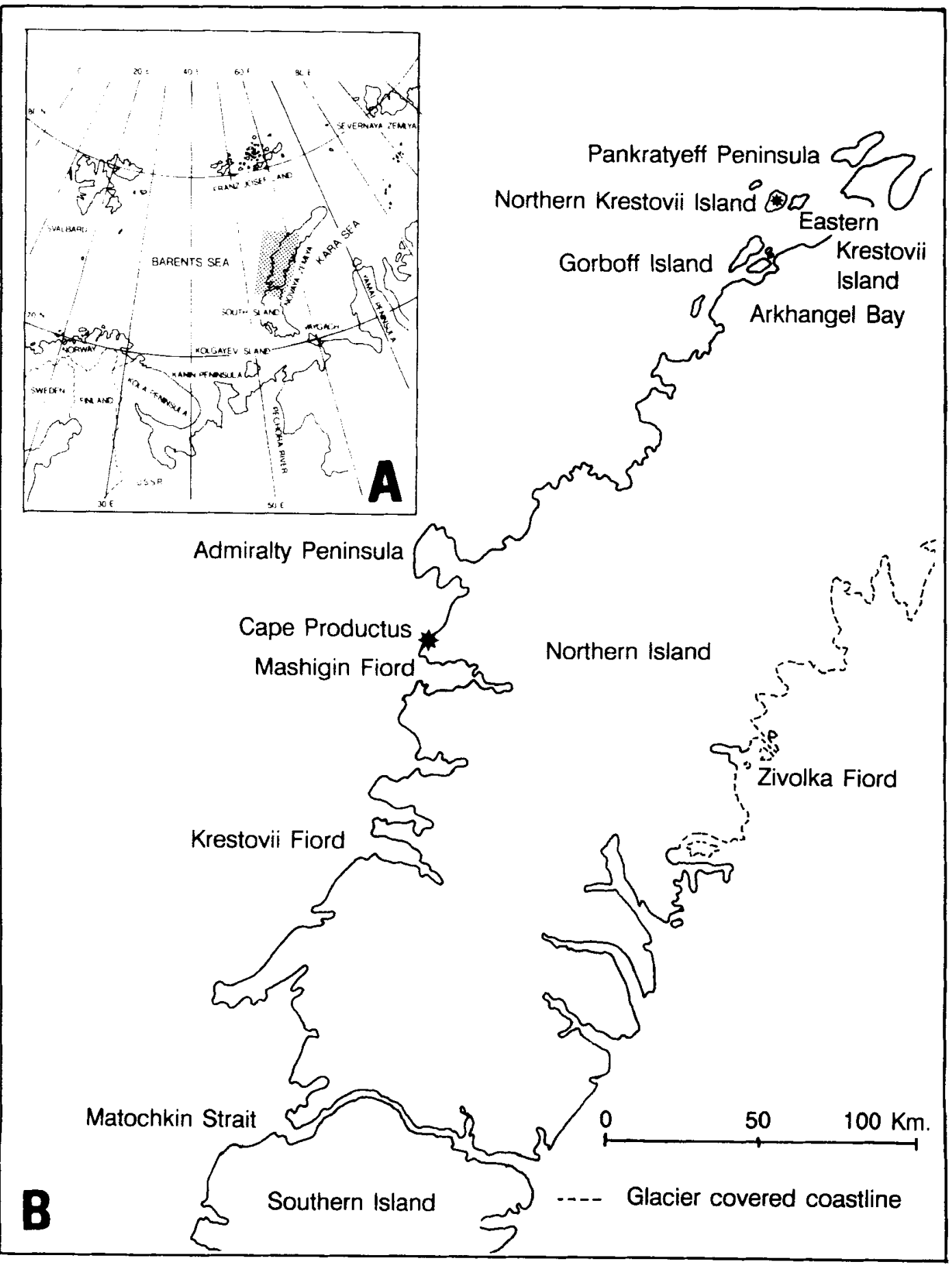

Fig. 1 .

A. Index map of the European Arctic region. Shaded area enlarged in B

B. Detail map of middle and southern part of the northern island of Novaya Zemlya showing localities visited during the Norwegian Novaya Zemlya Expedition in 1921. Stars indicate the two localities where the fossils described herein were collected. 
University of Oslo. Collections are numbered PMO 120.720, 120.721, 120.724, 121.506-121.510 (rock samples); $121.470-121.479$ and $121.488-$ 121.504 (thin sections); 121.480-121.487 (acetate peels) and 121.505 (conodont slide).

\section{Conodonts}

Two conodont samples were processed using standard conodont techniques: buffered acetic acid digestion and bromoform separation. One sample came from Zone 7 (Fig. 2) at Cape Productus, the other from the fusulinid-rich beds at Eastern Krestovii Island. The latter, a carbonate cemented siltstone $(1.7 \mathrm{kilo}$, of which 1.0 was digested), contained no conodonts, whereas the bioclastic limestone from Zone 7 contained ten conodont elements in a 4.8 kilo sample of which 3.8 kilo was digested.

Three genera and species have been identified from well-preserved platform ( $\mathrm{Pa}$ ) elements: Idiognathodus cf. delicatus Gunnell, Streptognathodus cf. parvus Dunn and Declinognathodus cf. noduliferus (Ellison \& Graves). This conodont faunule is of Vereiskian-Kashirskian (earliest Moscovian) age of the Russian scheme; comparable to the Morrowan-Atokan Series of the North American reference section.

Unpublished conodont data exists from Cape Borisoff, close to Cape Productus (N. N. Sobolev, pers. commun. 1990): Streptognathodus gracilis Stauffer and Plummer and $S$. elongatus Gunnell have been extracted from limestones correlative to Zone 9 (see Fig. 2); Streptognathodus oppletus Ellison from samples correlative to Zone 7; and Idiognathoides cf. sulcata Higgins and Bouckaert and Idiognathodus delicatus Gunnell from limestones correlative to the lowermost part of Zone 5.

The Cape Productus sample contained abundant fusulinids, crinoid stems and brachiopods (Choristites mosquensis), as well as a high proportion of indigestible light-coloured grains, probably quartzitic sand.

\section{Fusulinids}

Abundant fusulinids were investigated from the Eastern Krestovii Island sample and from the two Cape Productus samples, and fifteen taxa have been identified. A summary of the biostratigraphic implications given by the fusulinid fauna follows.
The lower sample from Cape Productus is of latest earliest Moscovian (Vereiskian) age as based on occurrences of Pseudostaffella gorskyi Grozdilova and Lebedeva, P. paracompressa Safonova and Profusulinella cf. staffellaeformis Kireeva. The upper sample from Cape Productus with Pseudostaffella cf. antiqua (Dutkevich), Neostaffella cf. greenlandica (Ross and Dunbar), $N$. sphaeroidea (Ehrenberg) and Profusulinella prisca (Deprat) is of late early Moscovian (Kashirskian) age. The fusulinid sample from Eastern Krestovii Island containing Profusulinella priscoidea Rauzer-Chernousova is of a late early Moscovian (Vereiskian-Kashirskian) age.

Similar fusulinid fauna has in part been reported from the Timan-Pechora and Moscow Basins (Rauzer-Chernousova et al. 1951; Grozdilova \& Lebedeva 1960), Svalbard (Forbes 1960; Cutbill \& Challinor 1965; Nilsson 1988; Simonsen, unpubl. data), eastern North Greenland (Ross \& Dunbar 1962), and Canada (Ross \& Monger 1978).

\section{Bryozoans}

After the digestion of the conodont sample from Cape Productus, several bryozoan colonies were extracted from the remaining limestone pieces. Some bryozoans were also prepared from fusulinid samples. Four taxa, including one new species, are described below. Bryozoans are scarce in the investigated samples and are not indicative of a particular age. However, the occurrence of Tabulipora cf. aliutovensis Shul'ga-Nesterenko in the upper Cape Productus sample suggests an early Moscovian age for this sample. Prismopora holtedahli n.sp. co-occurs with Tabulipora cf. aliutovensis Shul'ga-Nesterenko.

\section{Taxonomic remarks}

\section{Bryozoans}

\section{Order Cystoporata}

Fistulipora sp. A.

Fig. 3G-H.

Remarks. - One single zoarium of a species of Fistulipora was found. The zoarium is made up of an encrusting sheet with large and widely spaced zooecial apertures. Rounded and slightly oval apertures measure $0.38-0.45 \mathrm{~mm}$ in diameter, 


\begin{tabular}{|c|c|c|c|c|c|}
\hline 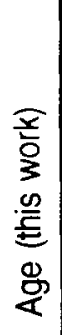 & 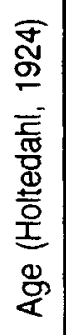 & 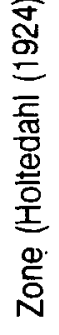 & $\begin{array}{l}\text { के̀ } \\
\text { 을 } \\
\stackrel{\Xi}{\Xi}\end{array}$ & 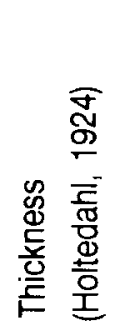 & $\begin{array}{l}\text { Fauna (Holtedahl, 1924; Sobolev and } \\
\text { Matweew, pers. comm. 1990) }\end{array}$ \\
\hline & & 10 & = & & \\
\hline & \multirow{2}{*}{ 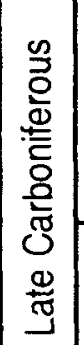 } & 9 & 11 & $\begin{array}{l}15-20 \\
\text { metres }\end{array}$ & 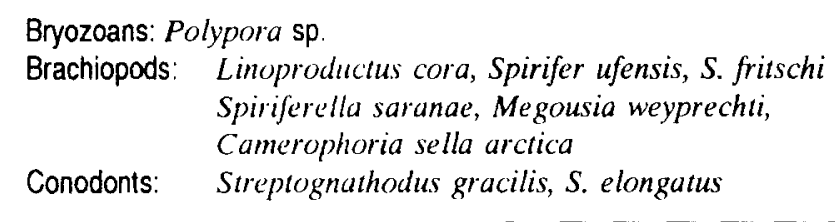 \\
\hline & & 8 & & $\begin{array}{l}? 5 \\
\text { metres }\end{array}$ & Corals \\
\hline 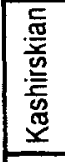 & \multirow{2}{*}{ 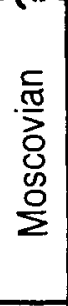 } & 7 & 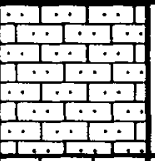 & $\begin{array}{l}\text { "Few } \\
\text { metres" }\end{array}$ & $\begin{array}{ll}\text { Brachiopods: } & \text { Meekella eximia, Choristites mosquensis, } \\
& \text { Neospirifer ?fasciger }\end{array}$ \\
\hline 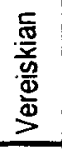 & & 6 & $\frac{15}{25}$ & & $\widehat{s}$ \\
\hline & & & & ?Break & \\
\hline & \multirow{2}{*}{ 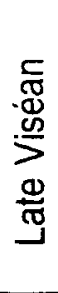 } & 5 & 2010 & & $\begin{array}{ll}\text { Conodonts: } & \begin{array}{l}\text { Idiognathoides cf. sulcata } \\
\text { Idiognathodus delicatus }\end{array} \\
\text { Brachiopods: } & \text { Striatifera striatus }\end{array}$ \\
\hline & & 4 & & & $\begin{array}{l}\text { Striatifera striatus } \\
\text { Chaetetes radians }\end{array}$ \\
\hline & & 3 & & & Striatifera strianus \\
\hline & & 2 & & & ?fusulinids, ?ooids \\
\hline & & 1 & क्टेंटे & $\begin{array}{l}\text { "Some } \\
\text { tens } \\
\text { metres" }\end{array}$ & Brachiopnds \\
\hline
\end{tabular}


with 2-4 apertures in $2 \mathrm{~mm}$ in all directions. Lunaria are well developed. The zoarium is interwoven with a species of Tabulipora (see below), and encrustation is interactive between these two forms. As only one tangential section was made, further observations were not possible. However, the few details observed indicate that this species is most similar to $F$. monoseriata Shul'ga-Nesterenko described from the Russian Platform, in strata of Steschevskian (middle Serpukhovian) age.

Genus Prismopora Hall, 1883

Type species Prismopora triquetra Hall and Simpson, 1887 , from the middle Devonian of the Falls of the Ohio, Jefferson, Indiana, USA.

Generic diagnosis (abridged from Utgaard 1983). - Zoarium trifoliate, irregularly branching. Branches narrow, parallel-sided; faces concave; margins solid, non-celluliferous. Monticules lacking. Autozooecia with peristomes and lunaria; lunaria on proximal side of autozooecia in row in center of branch; rotated to progressively more lateral position in rows of autozooecia toward branch margin. Mesotheca with central layer granular, outer layers granular-prismatic. Autozooecia partially isolated at mesotheca by vesicular tissue; subcircular in cross-section in exozone. Vesicular tissue forming small, low blisters in endozone and inner exozone; granularprismatic; stereom in most of exozone, with acanthostyles.

Prismopora holtedahli Nakrem n. sp.

Fig. 3A-F.

Diagnosis. - Trifoliate zoarium with unusually protruding lobes; large and widely separated zooecial apertures as well as large zoarial dimensions.

Description. - Zoarium is trifoliate with lobes diverging at $145^{\circ}, 130^{\circ}$, and $85^{\circ}$ angles. Zoarial lobes are $1.25-1.62 \mathrm{~mm}$ thick. One lobe protrudes $7.75 \mathrm{~mm}$ from zoarial central axis, the other two lobes are fragmented and their dimensions are not measured. Zooecial apertures are arranged more or less in regular rows. Distance between apertural centers is $0.60-0.90 \mathrm{~mm}$ (mean 0.77 ; STD (Standard deviation) 0.12; CV (Coefficient of variation $=\mathrm{STD}^{*} 100 /$ Mean) 15.18 ) measured along surface. Same distance measured diagonally: $0.45-0.63 \mathrm{~mm}$ (mean $0.52 \mathrm{~mm}$; STD 0.05 ; CV 8.86). Zooecial apertures are slightly oval with a weakly-developed lunarium and peristome. Apertures measure commonly $0.24 \mathrm{~mm} \times$ $0.22 \mathrm{~mm}$ (STD 0.02 and $0.01 ; \mathrm{CV} 8.17$ and 6.07 respectively). There are $2-3.5$ apertures along

\section{LEGEND: \\ is : Conodont, bryozoan and upper fusulinid sample \\ 象解: Lower fusulinid sample}

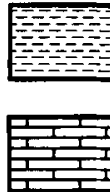

Dark shale

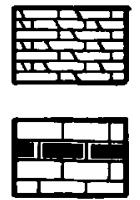

Dolomitic "wackestone"

Grey limestone

Alternating dark and

white limestones

II coral limestone

with chert nodules

Crystalline dolomite

Trك

wanci, white

Sandy, white

limestone

Fig. 2. Simplified lithological section at Cape Productus reconstructed according to information from Holtedahl (1924) and after discussions with Dr. V. Matweew and Dr. N. N. Sobolev (Leningrad). Fossil taxa is in accordance with modern nomenclature. in some cases different from that listed by Holtedahl. 

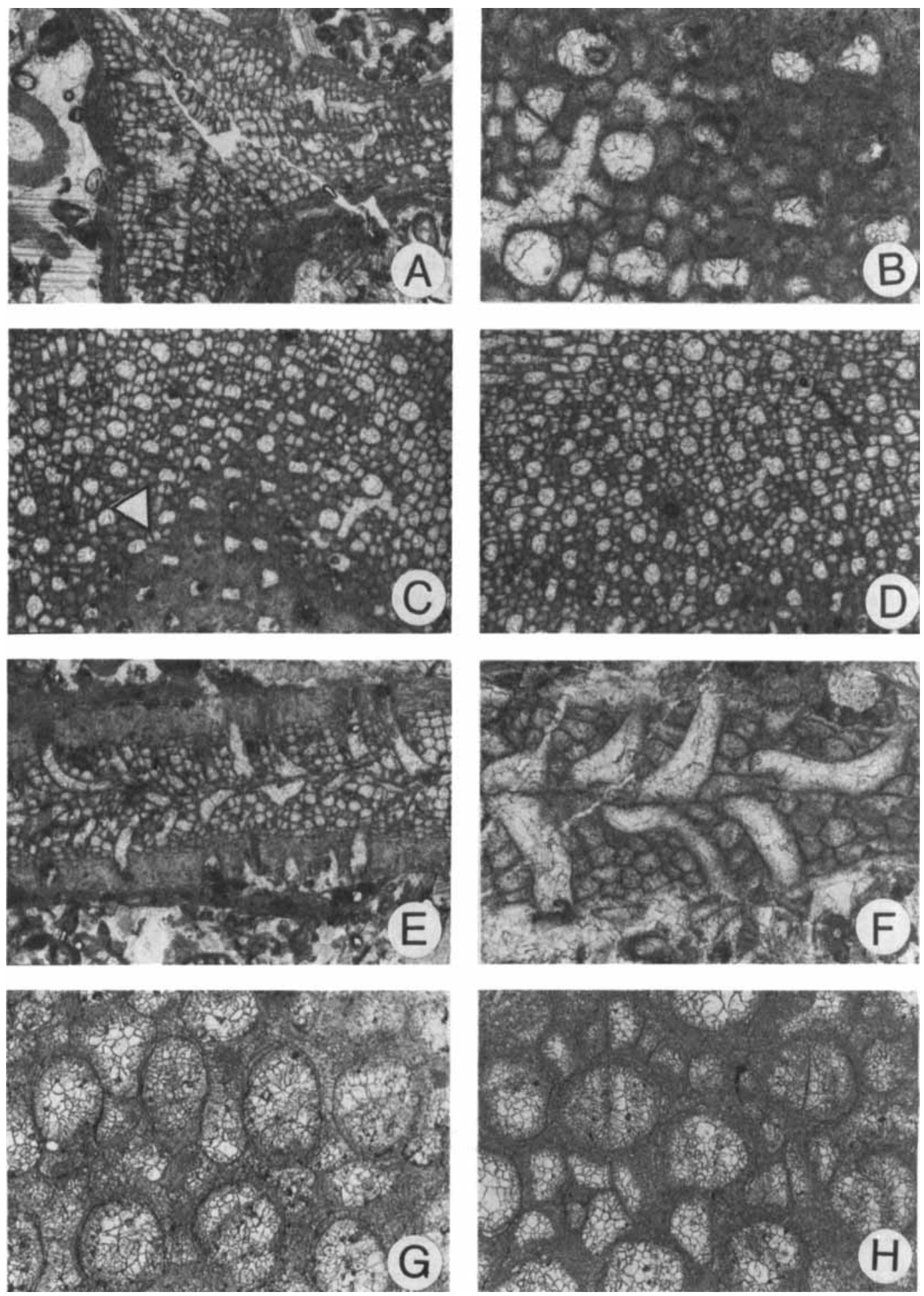
colony per $2 \mathrm{~mm}$ (mean 2.5 ; STD 0.46 ; CV 18.24) and 3.5-5 diagonally (mean 4; STD 0.44; CV 10.66 ). Peristome width is $0.012-0.016 \mathrm{~mm}$. Vesicles are developed between autozooecial tubes, and small amounts of stereom is present in exozone. Locally more massive stereom is developed in outermost exozone. Diaphragms are absent from autozooecial tubes.

Remarks. - The quantitative data obtained from the investigated material excludes this species from those previously described. The Australian species of Prismopora described by Crockford (1957) display closer spaced zooecial apertures, while $P$. triangulata Kiseleva is distinguished in possessing diaphragms in zooecial tubes. The species described by Hall \& Simpson (1887) lack some quantitative data for comparison, but zoarial dimensions seem to be smaller than those measured from the Novaya Zemlya specimens. Species of Prismopora are previously only known from the Devonian and Carboniferous of North America, from Lower Permian deposits of Australia and from Upper Permian deposits of the U.S.S.R. (Maritime Territory). Thus this new species described here is the first known representative from outside the Tethys biogeographical province.

Material. - Four specimens embedded in grayish white limestone. Each quantitative character in description is measured on at least 15 points.

Types. - Holotype PMO 121.479 (thin section); paratypes PMO 121.509, 121.510 (rock specimens).

Etymology. - The species is named in honour of Professor Olaf Holtedahl who collected the investigated material during his Novaya Zemlya expedition in 1921.
Type locality. - Cape Productus, Novaya Zemlya.

Age. - Choristites mosquensis brachiopod zone; Profusulinella prisca fusulinid zone. Moscovian (Kashirskian) age.

\section{Order Trepostomata}

Tabulipora aliutovensis Shul'ga-Nesterenko, 1955 Fig. 4D-H.

cf. 1951 Tabulipora aliutovensis Shul'ga-Nesterenko, pp. 88-89, pl. 8, figs. 8-9, pl. 11 , fig. 4 .

Description. - Three fragmented zoaria showing a ramose branching and encrusting growth were found. Cylindrical branches with diameter of $3.6 \mathrm{~mm}$; exozone $0.32-0.36 \mathrm{~mm}$; self over grown layers $0.40 \mathrm{~mm}$ and thicker. Zooecial apertures oval; $0.36 \mathrm{~mm}$ long and $0.18 \mathrm{~mm}$ wide; 5 apertures per $2 \mathrm{~mm}$ in any direction. One hook-like diaphragm present in zooecial tubes in outermost exozone. Acanthostyles developed in autozooecial corners; $0.09-0.11 \mathrm{~mm}$ in diameter; $3-4$ per autozooecial aperture. Exozonal walls fairly thick $(0.15-0.18 \mathrm{~mm})$ where acanthostyles are developed; 0.05-0.07 $\mathrm{mm}$ between acanthostyles. Geometry of endozonal zooecial tubes was not observed due to randomly oriented sections.

Remarks. - The investigated zoaria show evidence of hostile environmental conditions or competition with several stages of self over growth, and inter-woven growth together with Fistulipora (see above). Brachiopod spines are trapped between stages of growth, and it is believed that this species originally encrusted brachiopod shells, probably in a high-energy environment.

Age. - Tabulipora aliutovensis Shul'ga-Nesterenko was originally described from the Russian Platform, from the Vereiskian Horizon (early Moscovian).

Fig. 3. Bryozoans from Cape Productus. All are photographed from petrographic thin sections, except where noted.

A. Prismopora holtedahli Nakrem n. sp., transverse section showing trifoliate zoarium, $10 \times$, PMO 121.479, holotype.

B. Prismopora holtedahli Nakrem n. sp., tangential section, $10 \times$, PMO 121.480.

C. Prismopora holtedahli Nakrem n. sp., oblique tangential section showing massive stereom in shallowest exozone (arrow), $10 \times$, PMO 121.480 .

D. Prismopora holtedahli Nakrem n. sp., deep tangential section, $10 \times$, PMO 121.480.

E. Prismopora holtedahli Nakrem n. sp., transverse section of proximal lobe showing distinctive exozonal stereom, $10 \times$, PMO 121.479, holotype.

F. Prismopora holtedahli Nakrem n. sp., transverse section of distal lobe, $25 \times$, PMO 121.481.

G. Fistulipora sp. A., deep tangential section, $25 \times$, PMO 121.482, acetate peel.

H. Fistulipora sp. A., shallow tangential section, $25 \times$, PMO 121.482, acetate peel. 

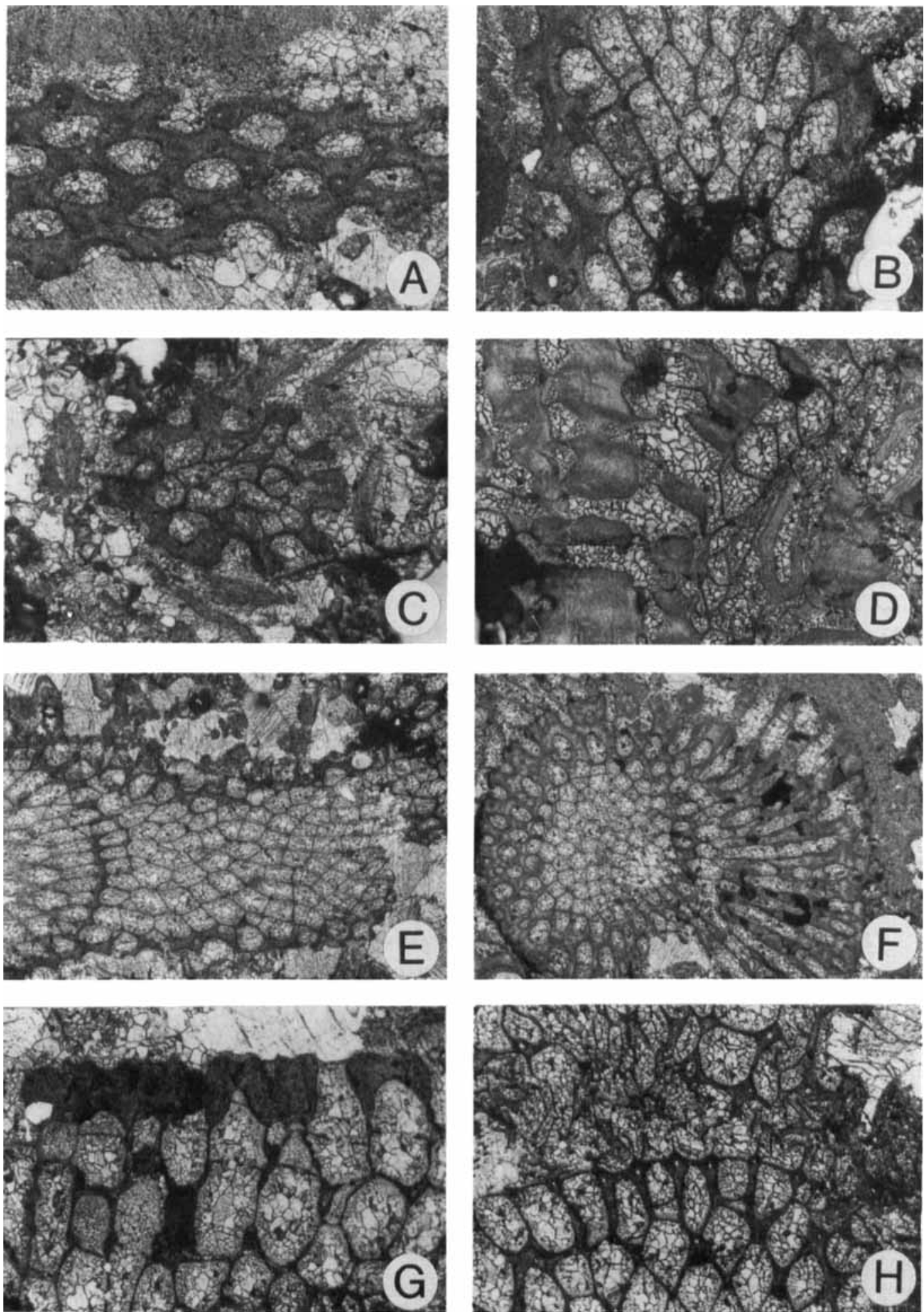
Order Cryptostomata

Ascopora sp. A.

Fig. $4 \mathrm{~A}-\mathrm{C}$.

Remarks. - One single zoarium of Ascopora was found, and only a few measurements could be made on a shallow to deep tangential section. Diameter of cylindrical zoarium exceeds $1.80 \mathrm{~mm}$; probably $2.00 \mathrm{~mm}$. Oval zooecial apertures are arranged in regular rows; $5.5-6.5$ diagonally and 4 along colony surface per $2 \mathrm{~mm}$. Apertures measure $0.25-0.27 \mathrm{~mm} \times 0.14$ $0.18 \mathrm{~mm}$. One large acanthostyle is present between autozooecial apertures; diameter 0.10 $0.11 \mathrm{~mm}$. Smaller acanthostyles (paurostyles) are not observed, possibly due to inadequate preserved specimen, and/or the randomly oriented acetate peel. A single hemiseptum is developed in outer part of zooecial tubes.

Although possessing only one single hemiseptum, as based on the available measured characters, the closest described species is $A$. magniseptata Shul'ga-Nesterenko from the Gzhelian of the Russian Platform.

\section{Conodonts}

Idiognathodus cf. delicatus Gunnell, 1931

Fig. 5A.

cf. 1931 Idiognathodus delicatus Gunnell, p. 250, pl. 29, figs. 23-25.

Remarks. - Two partly broken adult specimens were found. Because the upper surfaces are abraded, diagnostic details are lacking and the species assignation is questioned. For description and synonymy, see Bender (1979).

Age. - Idiognathodus delicatus Gunnell has been described from several locations in North America (e.g. Gunnell 1931; Lane et al. 1971; Baese- mann 1973; Grayson 1984) with a MorrowanAtokan-Desmoinesian (Pennsylvanian) distribution. This species is also repeatedly reported from the U.S.S.R. with an early Moscovian (Barskov et al. 1982; Goreva 1984) to middle-late Carboniferous (Barskov 1983) range. It also occurs in the Otto Fiord and Nansen Formations (latest Carboniferous age) of the Sverdrup Basin, Arctic Canada (Bender 1979; Beauchamp et al. 1989, fig. 3).

Streptognathodus cf. parvus Dunn, 1966

Fig. 5C-D.

cf. 1966 Streptognathodus parvus Dunn, p. 1302, pl. 158, figs. 9-10.

Remarks. - Three specimens were extracted. Juvenile specimens of Idiognathodus are not easily differentiated from elements of Streptognathodus, but the material seems best assigned to $S$. cf. parvus Dunn.

Age. - Streptognathodus parvus Dunn was originally described from the Morrowan of Nevada and Oklahoma (Dunn 1966), and is also known from the early Moscovian (Vereiskian and Kashirskian Horizons) of the U.S.S.R. (Barskov et al. 1982; Goreva 1984). An Atokan distribution (Oklahoma) for Idiognathodus paruus Gunn is reported by Kent-Grubbs (1984).

\section{Declinognathodus cf. noduliferus (Ellison \& Graves 1941)}

Fig. 5B.

cf. 1941 Cavusgnathus nodulifera Ellison and Graves, p. 4, pl. 3, figs. 4, 6.

Remarks. - One specimen with a broken free blade was extracted. The platform itself shows enough taxonomic detail to suggest the present

Fig. 4. Bryozoans from Cape Productus. All are photographed from acetate peels.

A. Ascopora sp. A., shallow tangential section, $25 \times$, PMO 121.484.

B. Ascopora sp. A., deep, oblique tangential section, $25 \times$, PMO 121.484.

C. Ascopora sp. A., transverse section, $25 \times$, PMO 121.485.

D. Tabulipora cf. aliutovensis Shul'ga-Nesterenko, 1955, transverse exozone with regenerated and encrusting growth, $25 \times$, PMO 121.486.

E. Tabulipora cf. aliutovensis Shul'ga-Nesterenko, 1955, oblique longitudinal section, $10 \times$, PMO 121.483 .

F. Tabulipora cf. aliutovensis Shul'ga-Nesterenko, 1955, transverse section with regenerated growth (upper right). $10 \times$, PMO 121.486.

G. Tabulipora cf. aliutovensis Shul'ga-Nesterenko, 1955, longitudinal section, exozone only, $25 \times$, PMO 121.487.

H. Tabulipora cf, aliutovensis Shul'ga-Nesterenko, 1955, terminated growth, $25 \times$, PMO 121.483. 


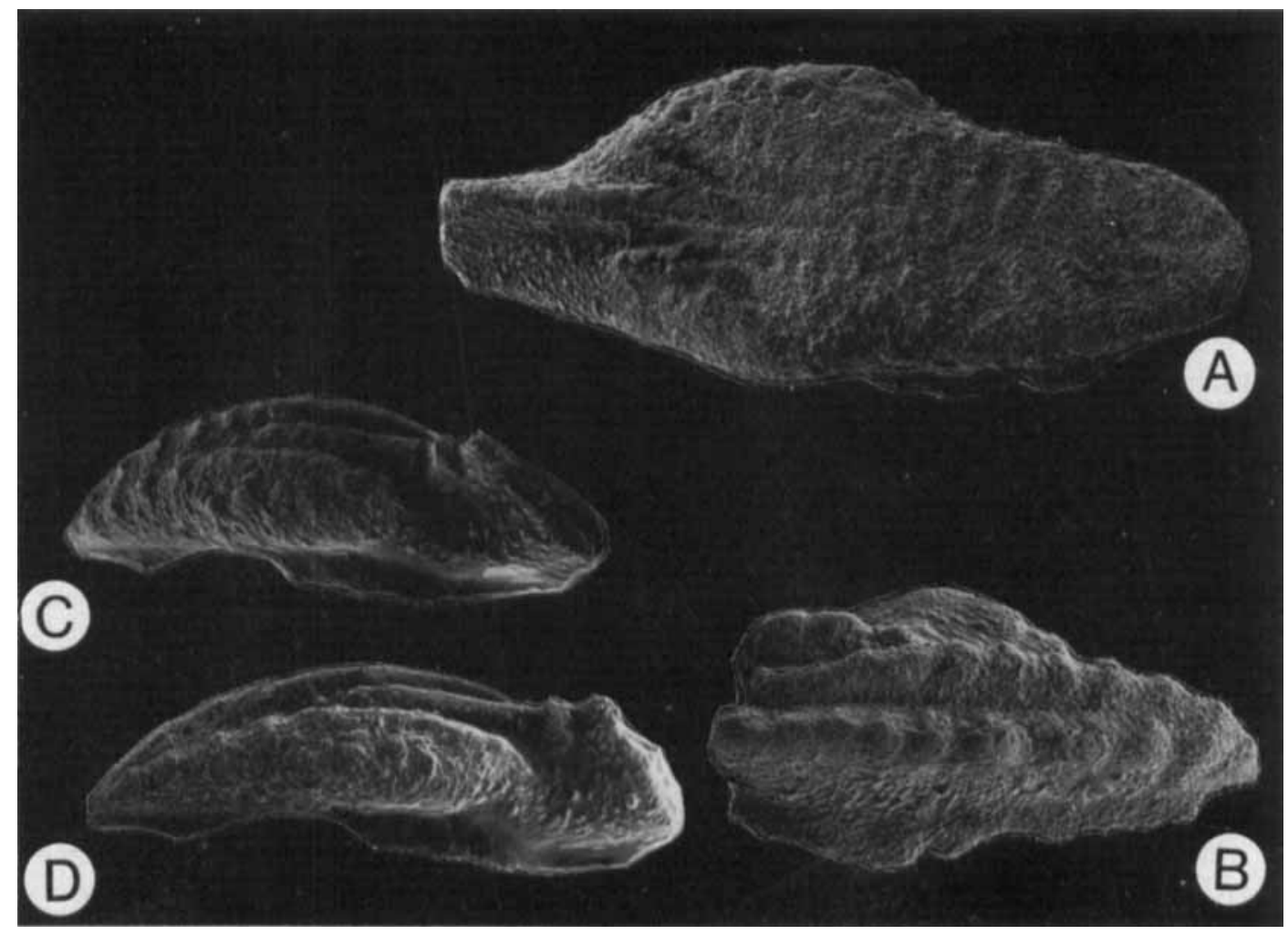

Fig. 5. Conodonts from the Cape Productus section.

A. Idiognathodus cf. delicatus Gunnell, 1931, 90 $\times$, PMO 121.505/2.

B. Declinognathodus cf. noduliferus (Ellison \& Graves 1941). 60) $\times$. PMO 121.505/4

C. Srreprognathodus ct. paruas Dunn, 1966, 60 $\times$. PMO 121.505/3

D. Streptognathodus of. parvus Dunn. 1966. $60 \times$. PMO 121.505/3

assignment. For further description and Fusulinids

synonymy, see Grayson (1984).

Age. - Declinognathodus noduliferus (Ellison and Graves) has been described from North America from the lower part of the Morrowan Series (Lane 1967; Dunn 1970; Grayson 1984) as well as from Great Britain (Higgins 1985) in strata of middle Namurian age. Occurrences in the U.S.S.R. (Moscow Basin) are reported by Goreva (1984) and Barskov et al. (1982) from the Vereiskian Horizon (early Moscovian). In the Sverdrup Basin this species is index species for the $D$. noduliferus zone with occurrence in the Otto Fiord and Nansen Formations (latest Carboniferous age) (Bender 1979; Beauchamp et al. 1989. fig. 3).
Note: Synonymy includes only major reassignments. Confusion exists because of deviating taxonomic usage between Soviet and western fusulinid workers.

\section{Pseudoendothyra moelleri (Ozawa 1925)}

Fig. 6I.

1925 Staffella moelleri Ozawa, pp. 19-20, pl. 2, fig. 9.

1951 Parastaffella moelleri (Ozawa); RauzerChernousova in Rauzer-Chernousova et al., p. 151, pl. 12, fig. 19, 20.

1963 Pseudoendothyra moelleri (Ozawa); Rozovskaya, p. 30.

Material and occurrence. - One axial and three 
slightly tangential sections from the Eastern Krestovii Island sample.

Measurements. - Specimens of 5 volutions reach approximately $1.0 \mathrm{~mm}$ in length and $1.1 \mathrm{~mm}$ in diameter; form ratio 0.9 .

Remarks. - P. moelleri (Ozawa) resembles $P$. pseudosphaeroidea (Dutkevich), but the latter has a more spherical outline, specially in the inner whorls.

Age. - Bashkirian to late Moscovian (Myachkovskian) in the Timan-Pechora and Moscow Basins (Rauzer-Chernousova et al. 1951).

\section{Pseudoendothyra timanica (Rauzer-Chern-} ousova) 1951

Fig. $6 \mathrm{H}$.

1951 Parastaffella timanica Rauzer-Chernousova in Rauzer-Chernousova et al., pp. 148-149, pl. 12, fig. 12, 13.

1963 Pseudoendothyra timanica (Rauzer-Chernousova); Rozovskaya, p. 30.

Material and occurrence. - One slightly tangential and three randomly oriented sections from the Eastern Krestovii Island sample.

Measurements. - Specimen of 4.5 volutions measures approximately $0.7 \mathrm{~mm}$ in length and $1.1 \mathrm{~mm}$ in diameter; form ratio 0.6 .

Remarks. - This species resembles closely to $P$. umbonata (Rauzer-Chernousova) but is less involute than the latter.

Age. - Moscovian in the Timan-Pechora and Moscow Basins (Rauzer-Chernousova et al. 1951).

Pseudoendothyra umbonata (Rauzer-Chernousova 1951)

Fig. 6G.

1951 Parastaffella umbonata Rauzer-Chernousova in Rauzer-Chernousova et al., p. 147, pl. 12, fig. 7-9.

1963 Pseudoendothyra umbonata (Rauzer-Chernousova); Rozovskaya, p. 31.

Material and occurrence. - Four axial and some slightly tangential sections from the Eastern Krestovii Island sample.
Measurements. - Specimen of 5 volutions measures approximately $0.5 \mathrm{~mm}$ in length and $1.3 \mathrm{~mm}$ in diameter; form ratio 0.4 .

Remarks. - P. umbonata (Rauzer-Chernousova) resembles $P$. poststruvei (Rauzer-Chernousova) in the outline of the shell, but has a smaller form ratio.

Age. - Moscovian (Vereiskian to Myachkovskian) on the Russian Platform (Rauzer-Chernousova et al. 1951).

Pseudoendothyra? cf. mirabilis (Rauzer-Chernousova 1951)

Fig. 6E-F.

cf. 1951 Parastaffella? mirablis Rauzer-Chernousova in Rauzer-Chernousova et al., p. 152, pl. 12, figs. 21, 22.

Material and occurrence. - Two axial and some randomly oriented sections from the Eastern Krestovii Island sample.

Measurements. - Specimen of 4.5 volutions reaches a length of $0.6 \mathrm{~mm}$ and a diameter of approximately $0.6 \mathrm{~mm}$; form ratio 1.0 .

Remarks. - The present specimens are slightly different from P?. mirabilis (Rauzer-Chernousova) in having a more spherical outline of the test. This species is tentatively assigned to the genus Pseudoendothyra due to lack of welldefined wall-structure (?four layers) and the thickness of the wall.

Age. - Pseudoendothyra? cf. mirabilis (RauzerChernousova) is originally described from the late Moscovian (Myachkovskian) on the Russian Platform. The specimens present in the lower fusulinid sample are associated with Profusulinella priscoidea Rauzer-Chernousova which indicates an early Moscovian age.

\section{Eostaffella mixta Rauzer-Chernousova, 1951}

Fig. 6C-D.

1951 Eostaffella mixta Rauzer-Chernousova in Rauzer-Chernousova et al., pp. 50-60, pl. 1, figs. 34, 35.

Material and occurrence. - Two axial sections from the Eastern Krestovii Island sample.

Measurements. - Specimens of 3-4.5 volutions 

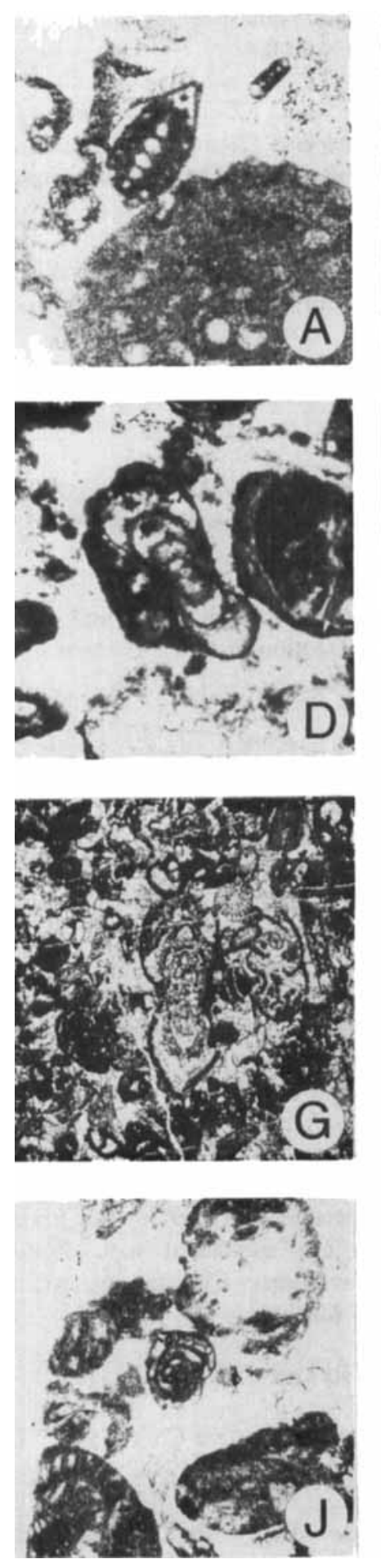
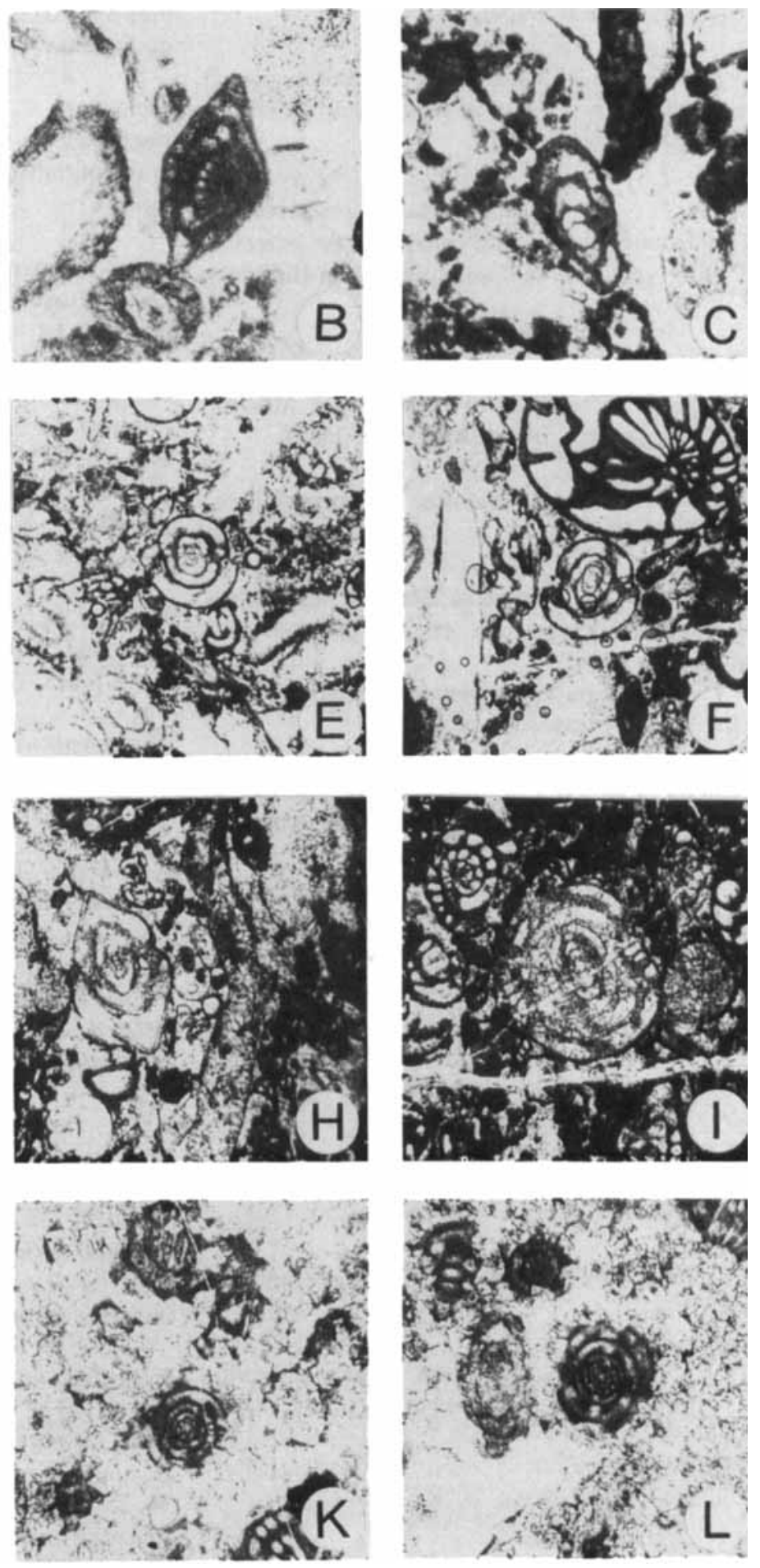
measure $0.25-0.30 \mathrm{~mm}$ in length and 0.50 $0.65 \mathrm{~mm}$ in diameter; form ratio 0.5 .

Age. - Bashkirian to early Moscovian on the Russian Platform (Rauzer-Chernousova et al. 1951.)

\section{Ozawainella sp. A.}

Fig. 6A-B.

Material and occurrence. - Randomly oriented sections from the upper fusulinid sample from Cape Productus.

Measurements. - Specimens of more than 3 volutions measure up to $0.3 \mathrm{~mm}$ in length and $0.60 \mathrm{~mm}$ in diameter; form ratio 0.5 .

Age. - Ozawainella sp. A is associated with $N$. greenlandica (Ross and Dunbar), N. sphaeroidea (Ehrenberg) and $P$. prisca (Deprat) in the investigated sample, and these species indicate an early Moscovian age.

Pseudostaffella cf. antiqua (Dutkevich, 1934)

Fig. 6J.

cf. 1934a Staffella antiqua Dutkevich, p. 35, textfigs. 4-6.

cf. 1950 Pseudostaffella antiqua (Dutkevich); Grozdilova and Lebedeva, pp. 30-31, pl. 3, figs. $8,9$.

Material and occurrence. - One axial section and some randomly oriented sections from the upper fusulinid sample from Cape Productus.

Measurements. - Specimen of 4.5 volutions meas- ures $0.4 \mathrm{~mm}$ in length and $0.5 \mathrm{~mm}$ in diameter; form ratio 0.8 .

Remarks. - The described species closely resembles $P$. antiqua (Dutkevich), but has broader chomata and a more square outline. $P$. cf. antiqua (Dutkevich) also resembles the morphology of $P$. paracompressa (Safonova), but is slightly smaller and has more loosely coiled early whorls.

Age. - P. antiqua (Dutkevich) is a characteristic species in the early Bashkirian but ranges into earliest Moscovian. The associated species, $N$. greenlandica (Ross and Dunbar), N. sphaeroidea (Ehrenberg) and $P$. prisca (Deprat), indicate however an early Moscovian age.

Pseudostaffella paracompressa Safonova, 1951. Figs. 6K-L and 7A.

1951 Pseudostaffella paracompressa Safonova in Rauzer-Chernousova et al., p. 100, pl. 5, figs. 12, 13.

Material and occurrence. - Two axial and many randomly oriented sections from the lower fusulinid sample from Cape Productus.

Measurements. - Specimens of 4 to 5 volutions reach approximately a length of 0.5 to $0.6 \mathrm{~mm}$ and a diameter of 0.6 to $0.9 \mathrm{~mm}$; form ratio of 0.7 to 0.8 .

Remarks. - This species resembles Pseudostaffella compressa (Rauzer-Chernousova) and $P$. praegorskyi Rauzer-Chernousova in size and shape of shell, but the chromata are less massive. The

Fig. 6. Fusulinids.

A, B. Ozawainella sp. A, A: tangential section, $40 \times$, PMO 121.473; B: tangential section, $40 \times$, PMO 121.472. Upper fusulinid sample from Cape Productus.

C, D. Eostaffella mixta Rauzer-Chernousova, 1951, C: axial section, $40 \times$, PMO 121.488; D: axial section. $40 \times$, PMO 121.491. From the Eastern Krestovii Island.

E, F. Pseudostaffella? cf. mirabilis (Rauzer-Chernousova), 1951, E: axial section, $20 \times$, PMO 121.492; F: axial section, $20 \times$, PMO 121.494. From the Eastern Krestovii Island.

G. Pseudoendothyra umbonata (Rauzer-Chernousova), 1951, axial section, $20 \times$, PMO 121.488. From the Eastern Krestovii Island.

H. Pseudoendothyra timanica (Rauzer-Chernousova), 1951, axial section, 20 ×, PMO 121.493/5. From the Eastern Krestovii Island.

I. Pseudoendothyra moelleri (Ozawa 1925), axial section, $20 \times$, PMO 121.493/4. From the Eastern Krestovii Island.

J. Pseudostaffella cf. antiqua (Dutkevich 1931), axial section, $20 \times$, PMO 121.475/2. Upper fusulinid sample from Cape Productus.

K, L. Pseudostaffella paracompressa Safonova, 1951, K: axial section, $20 \times$, PMO 121.499/1; L: axial section, $20 \times$, PMO 121.502/1. Lower fusulinid sample from Cape Productus. 

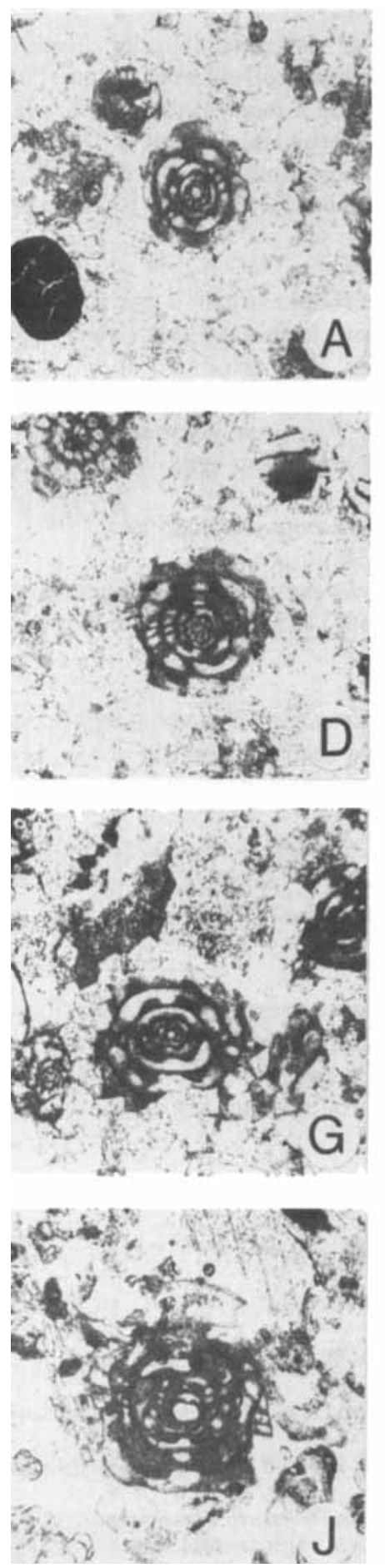

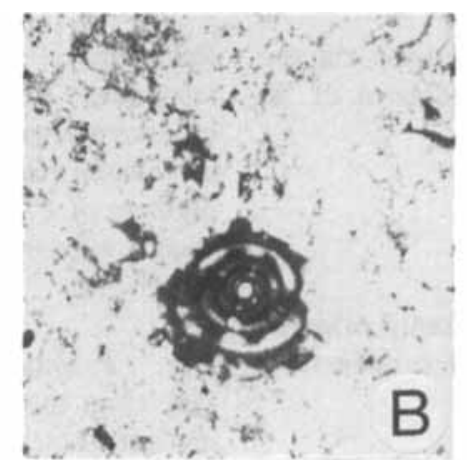

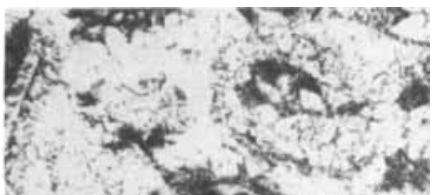

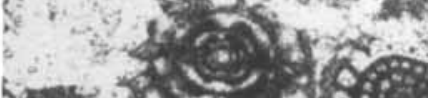

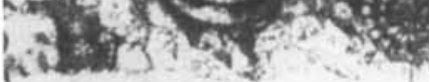

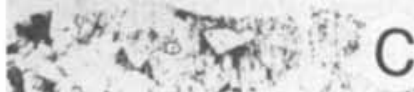

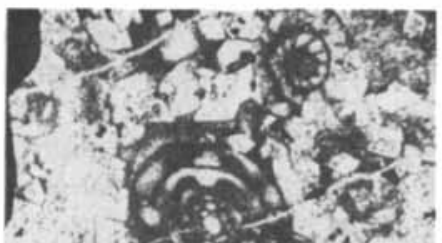

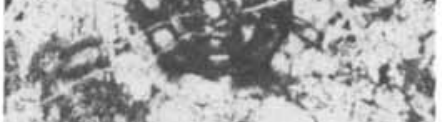

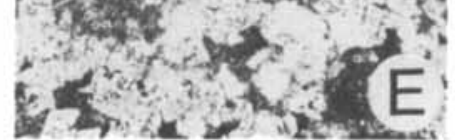
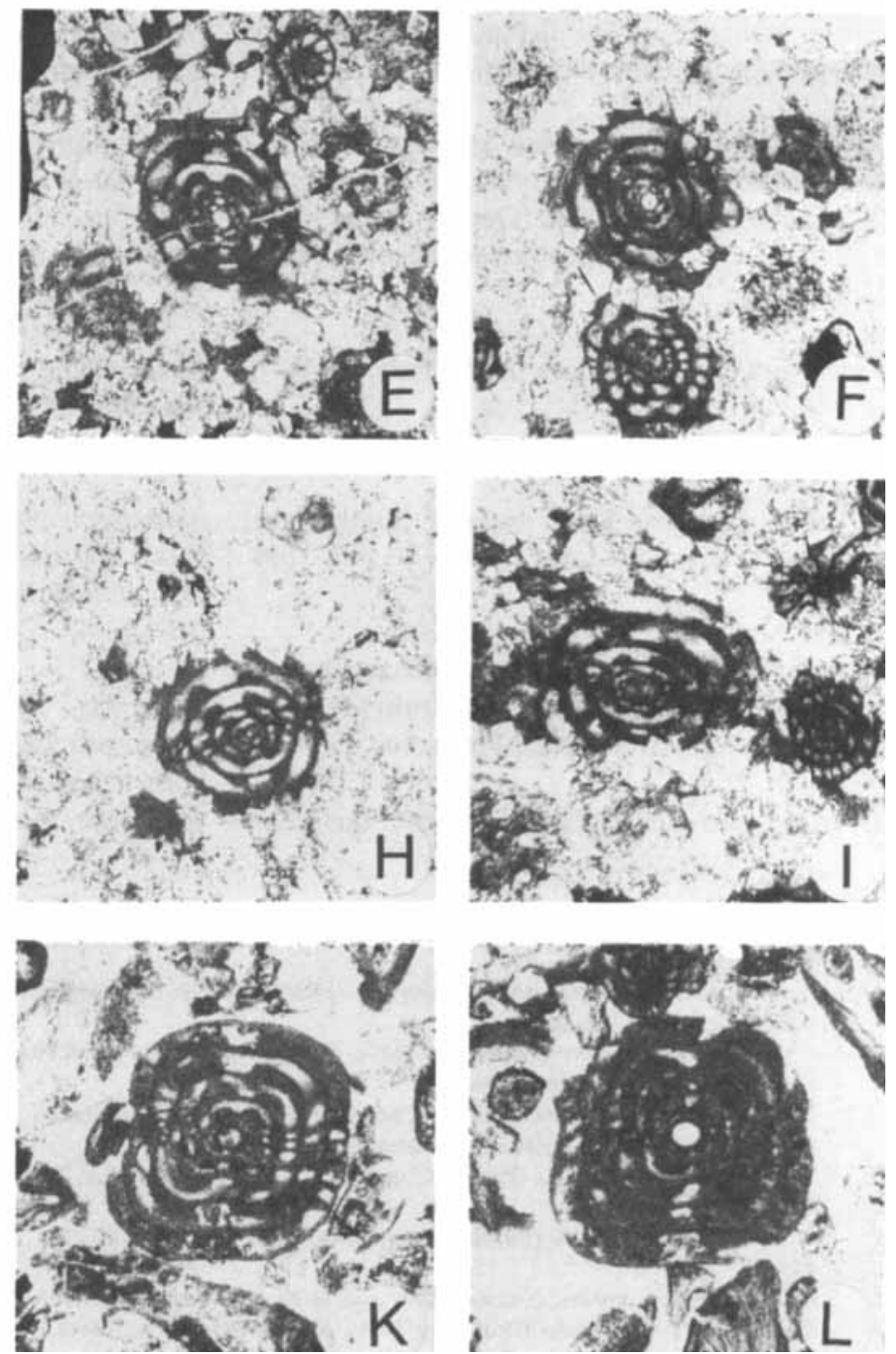
investigated specimens are badly preserved in outer volutions due to extensive dolomitisation.

Age. - Pseudostaffella paracompressa Safonova is a characteristic species in the early Moscovian (Vereiskian) on the Russian Platform (RauzerChernousova et al. 1951) and Canada (Ross \& Monger 1978).

\section{Pseudostaffella gorskyi (Dutkevich 1934)}

Fig. 7B-F.

1934b Staffella sphaeroidea var. gorskyi Dutkevich, pp. 119-122, pl. 2, figs. 16, 17.

1950 Pseudostaffella gorskyi (Dutkevich) Grozdilova and Lebedeva, pp. 37-38, pl. 4, figs. 5-7.

Material and occurrence. - Two axial and some randomly sections prepared from the lower fusulinid sample from Cape Productus. The specimens are badly preserved in outer volutions due to extensive dolomitisation.

Measurements. - Specimens of 5 whorls measure approximately $0.8 \mathrm{~mm}$ to $1.0 \mathrm{~mm}$ in length and $0.8 \mathrm{~mm}$ to $1.0 \mathrm{~mm}$; form ratio 0.8 to 1.0 .

Remarks. - Pseudostaffella gorskyi (Dutkevich) is different from $P$. praegorskyi Rauzer-Chernousova and $P$. paracompressa Safonova in having low chomata extending to the lateral shoulders. P. compressa Rauzer-Chernousova is similar in shape of shell and chomata, but is smaller. $N$. sphaeroidea (Ehrenberg) and $N$. subquadrata (Grozdilova and Lebedeva) are larger, commonly having much larger proloculus and chomata that extends to the poles. The latter also has a more square outline.

Age. - Pseudostaffella gorskyi (Dutkevich) ranges from late Bashkirian to early late Moscovian in the European part of U.S.S.R. (Rauzer-Chernousova et al. 1951; Grozdilova \& Lebedeva
1960; Semichatova et al. 1979). On Spitsbergen this species is associated with faunas of late Moscovian age (Nilsson 1988). On Bjørnøya $P$. gorskyi (Dutkevich) is associated with Profusulinella and Pseudostaffella of ?Bashkirianearly Moscovian age (Simonsen, unpubl. data). In Canada (British Columbia) this species is assigned to a possible Kashkirskian age on the basis of size and extent of the chomata (Ross \& Monger 1978). The specimens investigated in our work occur together with $P$. paracompressa Safonova which indicates a Vereiskian age.

\section{Neostaffella cf. greenlandica (Ross \& Dunbar 1962)}

Figs. 7J-L.

cf. 1962 Pseudostaffellagreenlandica Ross \& Dunbar, pp. 11-13, pl. 1, figs. 9, 10.

Material and occurrence. - Seven axial and several randomly oriented sections from the upper fusulinid sample from Cape Productus.

Measurements. - Specimens of 4 to 6 volutions measure 0.9 to $1.3 \mathrm{~mm}$ in length and 1.0 to $1.6 \mathrm{~mm}$ in diameter; form ratio 0.8 to 1.0 .

Remarks. - The investigated specimens agree generally to the type specimens of eastern North Greenland, but have two whorls less. Neostaffella sphaeroidea cuboides (Rauzer-Chernousova) is similar in size and number of volutions but has a more rounded outline and more massive chomata extending to the poles. Neostaffella subquadrata Grozdilova and Lebedeva is similar in shape of shell and number of whorls but it is different in having less-developed chomata not extending to the poles.

Age. - Neostaffella greenlandica (Ross \& Dunbar) occurs in late early to early late Moscovian (Kashirskian and Podolskian) on Northeast

Fig. 7. Fusulinids.

A. Pseudostaffella paracompressa Safonova, 1951, axial section, $20 \times$, PMO 121.498/1. Lower fusulinid sample from Cape Productus.

B-F. Pseudostaffella gorskyi (Dutkevich 1934), B: axjal section, $20 \times$, PMO 121.504; C: axial section, $20 \times$, PMO 121.499/3; D: axial section, $20 \times$, PMO 121.477; E: axial section, $20 \times$, PMO 121.470; F: axial section, $20 \times$, PMO 121.476. Lower fusulinid sample from Cape Productus.

G-I. Profusulinella cf. staffellaeformis Kireeva, 1951, G: axial section, $20 \times$, PMO 121.502/2; H: axial section, $20 \times$. PMO 121.503; I: axial section, $20 \times$, PMO 121.499/2. Lower fusulinid sample from Cape Productus.

J-L. Neostaffella greenlandica (Ross \& Dunbar 1962), J: axial section, $20 \times$, PMO 121.479/2; K: oblique axial section, $20 \times$, PMO 121.477/2; L: axial section, 20×, PMO 121.470. Upper fusulinid sample from Cape Productus. 

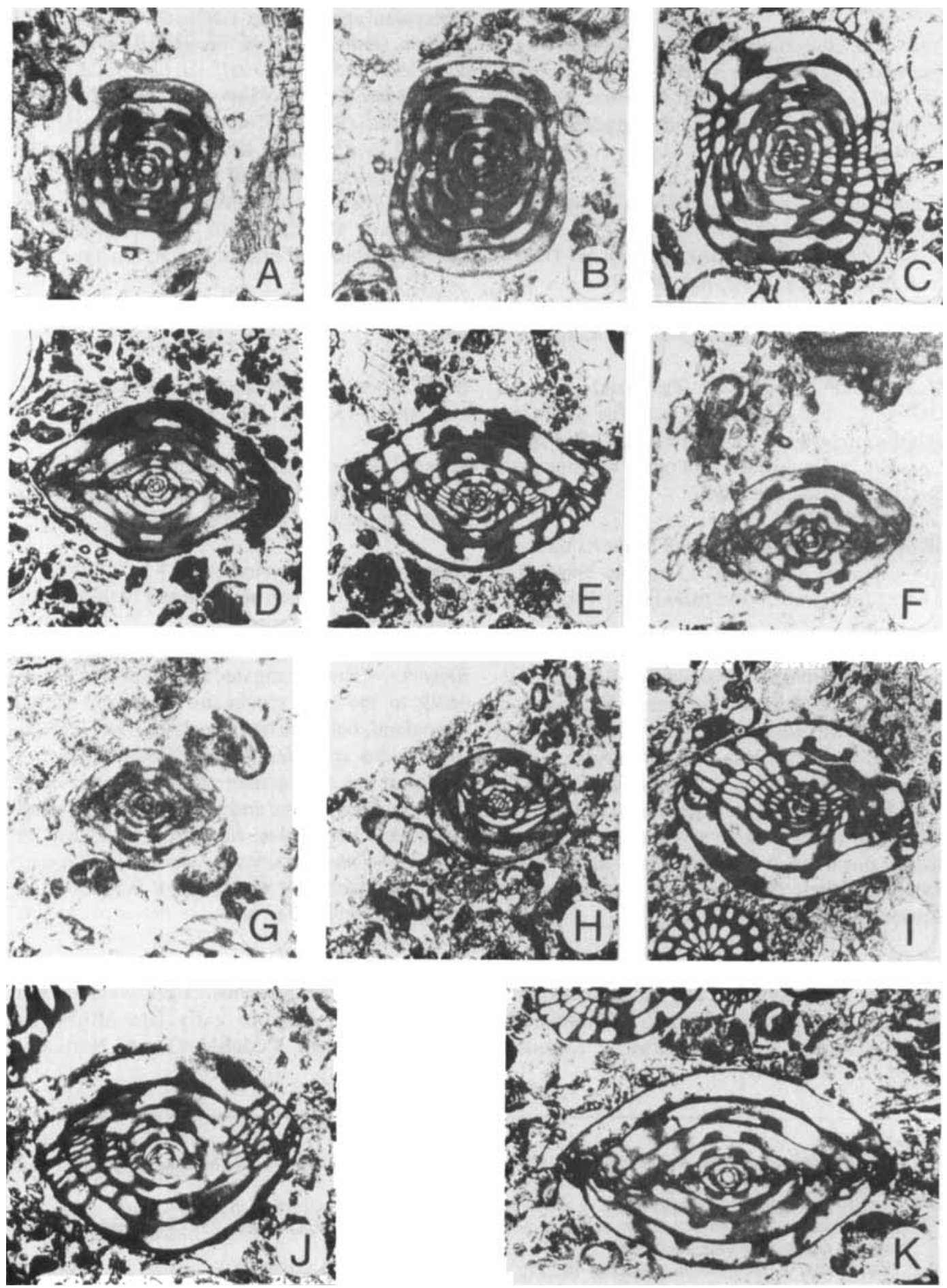
Greenland (Ross \& Dunbar 1962), and in the late early Moscovian (Kashirskian) on Spitsbergen (Nilsson 1988).

Neostaffella sphaeroidea (Ehrenberg 1842, sensu Möller 1878)

Fig. 8B.

1842 Melonia (Borelis) sphaeroidea Ehrenberg, p. 274.

1878 Fusulinella sphaeroidea (Ehrenberg); Möller, pp. 107-111, pl. 5, fig. 4a-e, pl. 15, fig. $1 \mathrm{a}, \mathrm{b}$.

1930 Pseudostaffella sphaeroidea (Ehrenberg); Lee et al., pp. 114-115, pl. 6, fig. 26.

1959 Neostaffella sphaeroidea Ehrenberg; Miklucho-Maklai, pp. 628-630.

Material and occurrence. - One axial and two randomly sections from the upper fusulinid sample from Cape Productus, and one randomly section from the Eastern Krestovii Island sample.

Measurements. - Specimens of 5 to 6 volutions measure approximately $1.2 \mathrm{~mm}$ to $1.5 \mathrm{~mm}$ in length and $1.6 \mathrm{~mm}$ to $1.9 \mathrm{~mm}$ in diameter; form ratio 0.8 .

Remarks. - The investigated specimens of Neostaffella sphaeroidea (Ehrenberg) resembles also N. umbilicata (Putrja and Leontovitch), but the latter has smaller test and chomata that thins more rapidly towards the poles.

Age. - N. sphaeroidea (Ehrenberg) is common in the late early Moscovian (Kashirskian) to late Moscovian (Podolskian and Myachkovskian) in the U.S.S.R. (e.g. Rauzer-Chernousova et al. 1951; Lebedeva 1966). This species also occurs in strata of late Moscovian age both on Spitsbergen (Nilsson 1988) and on Bjørnøya (Simonsen, unpublished data).
Neostaffella sp. A.

Fig. 8C.

Material and occurrence. - One slightly oblique and tangential section from the Eastern Krestovii Island sample.

Measurements. - The specimen reach a length of approximately $1.4 \mathrm{~mm}$ and a diameter of $1.9 \mathrm{~mm}$; form ratio of 0.7 .

Remarks. - This species is different from $N$. sphaeroidea (Ehrenberg) in having less lateral developed chomata.

Profusulinella cf. staffellaeformis Kireeva, 1951 Fig. 7G-I.

cf. 1951 Profusulinella staffellaeformis, Kireeva in Rauzer-Chernousova et al., p. 159, pl. 13, figs. $8,9$.

Material and occurrence. - Two axial and some randomly-oriented sections from the lower fusulinid sample from Cape Productus.

Measurements. - Specimens of 4 to 5 volutions measure 0.9 to $1.3 \mathrm{~mm}$ in length and 0.7 to $0.9 \mathrm{~mm}$ in diameter; form ratio 1.3 to 1.4 .

Remarks. - The investigated specimens of $P$. cf. staffellaeformis Kireeva have some morphological similarities to both $P$. parva Lee et al. and $P$. bona Grozdilova and Lebedeva.

Age. - Profusulinella staffellaeformis Kireeva ranges from Bashkirian to early Moscovian (Vereiskian) in the Urals and the Timan-Pechora Basin (Rauzer-Chernousova et al. 1951).

Fig. 8. Fusulinids.

A. Neostaffella greenlandica (Ross \& Dunbar 1962), axial section, $20 \times$, PMO 121.479/1. Upper fusulinid sample from Cape Productus.

B. Neostaffella sphaeroidea (Ehrenberg 1842), axial section, $20 \times$, PMO 121.471. Upper fusulinid sample from Cape Productus.

C. Neostaffella sp. A., oblique section, $20 \times$, PMO 121.478. Upper fusulinid sample from Cape Productus.

D-J. Profusulinella prisca (Deprat 1912), D: axial section, $20 \times$, PMO 121.489: E: axial section. $20 \times$, PMO 121.491; H: oblique tangential section, $20 \times$. PMO 121.494; I: oblique tangential section. $20 \times$, PMO 121.492; J: axial section, $20 \times$, PMO 121.496. From the Eastern Krestovii Island. F: axial section, $20 \times$, PMO 121.472; G: axial section, $20 \times$, PMO 121.476. Upper fusulinid sample from Cape Productus.

K. Profusulinella priscoidea Rauzer-Chernousova, 1938, axial section, 20×, PMO 121.493/1. From the Eastern Krestovii Island. 
Profusulinella prisca (Deprat 1912)

Fig. 8D-J.

1912 Schwagerina prisca Deprat, pp. 41-42, pl. 4, figs. 10-14.

1936 Profusulinella prisca (Deprat); RauzerChernousova et al., pp. 176-177, pl. 1, fig. 1.

Material and occurrence. - Investigated specimens include three axial sections from the Eastern Krestovii Island sample and three axial sections from the upper fusulinid sample from Cape Productus.

Measurements. - Specimens of 4 to 7 volutions measure 1.2 to $2.0 \mathrm{~mm}$ in length and 0.9 to $1.2 \mathrm{~mm}$ in diameter; form ratio 1.3 to 1.6 .

Remarks. - This species is distinguished from Profusulinella ovata Rauzer-Chernousova and $P$. priscoidea Rauzer-Chernousova in being more globose. The latter species also has more massive chomata.

Age. - Profusulinella prisca (Deprat) is widely distributed in strata of early Moscovian age in southeastern Asia and eastern Europe (RauzerChernousova et al. 1951; Grozdilova \& Lebedeva 1960), Spitsbergen (Nilsson 1988), Bjørnøya (Simonsen, unpubl. data) and western Canada (Ross \& Bamber 1978).

\section{Profusulinella priscoidea Rauzer-Chernousova, 1938}

Fig. $8 \mathrm{~K}$.

1938 Profusulinella priscoidea Rauzer-Chernousova, pp. 102-103, pl. 154, figs. 1-3.

Material and occurrence. - One axial section from the Eastern Krestovii Island sample.

Measurements. - Specimen of 6.5 whorls reach $2.5 \mathrm{~mm}$ in length and $1.5 \mathrm{~mm}$ in diameter; form ratio 1.7 .

Age. - Profusulinella priscoidea Rauzer-Chernousova ranges through the Lower Moscovian of the U.S.S.R.

Acknowledgements. - Dr. N.N. Sobolev and Dr. V. Matweew. Leningrad, provided valuable information on recent geological investigations on the Upper Palaeozoic successions of Novaya Zemlya Dr. David L. Bruton kindly read an early version of our manuscript and suggested valuable scientific and grammatical improvements. Mrs. T. Winje. Geological Institute, University of Oslo. helped on conodont SEM photography; Mr. $\varnothing$.
Rossing, IKU, prepared fusulinid and bryozoan thin sections. The Norwegian Research Council for Science and Humanities (NAVF) financed a visit to Leningrad (I. Nilsson and H. A. Nakrem).

\section{References}

Baesemann, J. F. 1973: Missourian (Upper Pennsylvannian) conodonts of northeast Kansas. Journal of Paleontology 47, 689-710.

Barskov, I. S. 1983: O konodontakh kamennoygolnykh otlozhenii Mysa Chaika (Yugo-Zapadnyi Pai-Khoy) [On the conodonts from the coal-bearing beds of Cape Chaika (southwestern Pay-Khoy)]. Doklady Akademii Nauk SSSR 270 (5), 1163-1166

Barskov, I. S., Alekseev. A. S. \& Goreva, N. V. 1982: Puti razvitiya platformennykh konodontov $v$ srednem i rozdnem karbone moskovskoi sineklizy i ikh znachenie dlya razrabotki zonalnoi shkaly (Ways of development of the platform conodonts in the middle and late Carboniferous of the Moscow syncline and their importance for the zonal division]. Pp. 15-34 in Mennera, V. V. and Drushscitsa, V. V. (Eds.): Zakonomernosti istoricheskogo razvitiya iskopaemykh organizmov (konodonty. foraminifery, rasteniva devonskie ryby) (Laws of the historical development of the fossil organisms (conodonts, foraminifers, plants, Devonian fish)). Izdatelstvo Moskovskogo Universiteta ( $M G U$ ).

Beauchamp, B., Harrison, J. C. \& Henderson, C. M. 1989: Upper Paleozoic stratigraphy and basin analysis of the Sverdrup Basin, Canadian Arctic Archipelago: Part 1, time frame and tectonic evolution. Current Research, Part G. Geological Survey of Canada. Paper 89-1G, 105-113.

Bender. K. P. 1979: Lower and Middle Pennsylvanian conodonts from the Canadian Arctic Archipelago. Geological Survey of Canada Paper 79-15. 29 pp.

Crockford, J. 1957: Permian Bryozoa from the Fitzroy Basin, Western Australia. Bureau of Mineral Resources, Geology and Geophysics Bulletin $34.92 \mathrm{pp}$.

Cutbill, J. L. \& Challinor, A. 1965: Revision of the stratigraphical scheme for the Carboniferous and Permian rocks of Spitsbergen and Bjørnøya. Geological Magazine 102, 418439.

Deprat, J. 1912: Étude géologique du Yun Nan Oriental. Pt. 3. Étude des Fusulinidés de Chine et d'Indochine et Classification des Calcaires á Fusulines. Memoires du Service géologique de l'IndoChine I. $76 \mathrm{pp}$.

Dunn, D. L. 1966: New Pennsylvanian platform conodonts from southwestern United States. Journal of Paleontology 40. 1294-1303.

Dunn, D. L. 1970: Middle Carboniferous conodonts from western United States and phylogeny of the platform group. Journal of Paleontology 44, 312-342.

Dutkevich, G. A. 1934a: K stratigrafii srednego karbona na Urale. [Sur la Stratigraphie du Carbonifere moyen de L'oural] Trudy Neftyanogo geologo-razvedochnogo Instituta, ser. A. 55. $41 \mathrm{pp}$.

Dutkevich, G. A. 1934b: Novye vidy fuzulinid iz verkhnego i srednego karbona Verkhne-Chusovskikh Gorodkov (zapadnyi sklona srednego Urala) [Some new species of Fusulinidae from the upper and middle Carboniferous of Verkhne-Chussovskye Gorodki on the Chussovaya River (Western slope of the central Urals]. Trudy Neftyanogo geologo-razvedochnogo Instituta, ser. A. $36.98 \mathrm{pp}$ 
Ehrenberg. C. G. 1842: Der Bergkalk am Onega See aus Polythalamien bestehand. Berichte der Königlichen Preussische Akademie der Wissenschaffen (Berlin), 273-275.

Ellison, S. P. \& Graves, R. W. 1941: Lower Pennsylvanian (Dimle Limestone) conodonts from the Marathon Region, Texas. University of Missouri School of Mines and Metallurgy Bulletin 15(3). 21 pp.

Forbes, C. L. 1960: Carboniferous and Permian Fusulinidae from Spitsbergen. Palaeontology 2, 210-225.

Fredericks, G. 1927: On some Moscowian Spiriferids from Novaya Zemlya. Report of the scientific results of the Norwegian expedition to Novaya Zemlya 1921, 35. $10 \mathrm{pp}$.

Goreva, N. V. 1984: Konodonty moskovskogo yarusa Moskovskoi sineklizy [Conodonts from the Moscovian Beds of the Moscow syncline]. Izd-vo MGI (Izdatelystoo Moskouskogo Universiteta), 44-122.

Grayson, R. C. Jr. 1984: Morrowan and Atokan (Pennsylvanian) conodonts from the northeastern margin of the Arbuckle Mountains, southern Oklahoma. Oklahoma Geological Survey Bulletin 136, 41-63.

Grozdilova, L. P. \& Lebedeva, N. S. 1950: Nekotorye vidy shtaffell Srednekamennougol'nykh Otlozheniye Zapadnogo Skona Urala [Certain species of Staffella from Middlc Carboniferous deposits of the western slope of the Urals]. Trudy VNIGRI, nov.ser., vyp. 50. Mikrofauna Neftyanykh mestorozhdeniy SSSR, sbornik, III, 5-46.

Grozdilova, L. P. \& Lebedeva, N. S. 1960: Foraminifery kamennougol'nykh Otlozheniy Zapadnogo Skona Urala i Timana. [Foraminifera from Carboniferous deposits of the western slope of the Urals and Timan]. Gostoptekhizdat Trudy VNIGRI, vyp. $150.264 \mathrm{pp}$.

Gunnell, F. H. 1931: Conodonts from the Fort Scott Limestone of Missouri. Journal of Paleontology 5, 224-252.

Hall, J. 1883: Bryozoans of the upper Helderberg groups. Transactions of the Albany Institute 10, 145-197.

Hall, J. \& Simpson, G. B. 1887: Paleontology of New York, Volume VI. Corals and Bryozoa. Natural History of New York. Albany, New York. 298 pp.

Heafford. A. P. 1988: Carboniferous through Triassic stratigraphy of the Barents Shelf. Pp. 89-108 in Harland, W. B. \& Dowdeswell, E. K. (Eds.): Geological Evolution of the Barents Shelf Region. Graham \& Trotman, London.

Higgins, A. C, 1985: The Carboniferous system: Part 2 - Conodonts of the Silesian Subsystem from Great Britain and Ireland. Pp. 210-227 in Higgins, A. C \& Austin, R. L. (Eds.): A Stratigraphical Index of Conodonts. Ellis Horwood L.td., Chichester.

Holtedahl, O. 1922: Brief account of the expedition. Report of the scientific results of the Norwegian expedition to Novaya Zemlya 1921, Vol. 1, No. 1. 14 pp.

Holtedahl, O. 1924: On the rock formations of Novaya Zemlya. Report of the scientific results of the Norwegian expedition to Novaya Zemlya 1921, Vol. 2, No. 22. 183 pp.

Holtedahl. O. 1930: Geology: Report of the scientific results of the Norwegian expedition to Novaya Zemlya 1921, var. pagination.

Kent-Grubbs, R. 1984: Conodont platform elements from the Wapanucka and Atoka Formations (Morrowan-Atokan) of the Mill Creek Syncline, Central Arbuckle Mountains, Oklahoma. Oklahoma Geological Survey Bulletin 136, 65-80.

Lane, H. R. 1967: Uppermost Mississippian and Lower Pennsylvanian conodonts from the type Morrowan Region, Arkansas. Journal of Paleontology 41, 920-942.

Lane, H. R., Merrill. G. K., Straka II, J. J. \& Webster, G. D. 1971: North American Pennsylvanian conodont biostra- tigraphy. Geological Society of America Memoir 127, 395 414.

Lebedeva, N. S. 1966: Foraminifery srednego karbona severnogo Timana [Foraminifera from the Middle Carboniferous of the northern part of Timan]. Trudy VNIGRI, nou. ser. vyp. 250. Mikrofauna SSSR Neftyanykh mestorozhdeniy sbornik 14, 176-253.

Lee, J. S.. Chen, S. \& Chu, S. 1930: The Huanglung limestone and its fauna. Memoirs of the National Research Institute of Geology 9, 85-i43.

Miklucho-Maklai, A. D, 1959: Znachenie gomcomorfii dlya sistematiki fuzulinid [The significance of homeomorphy for the systematics of the fusulinids]. Uchenye Zapitskie Leningradskogo ordena Lenina gosudarstvennogo universiteta im A. S. Bubnova 268, 155-172.

Möller, V. von 1878: Die spiral-gewundenen Foraminiteren des russischen Kohlenkalkes. Zapiski Imperatorskoi akademii nauk, Ser. 7 (25). 147 pp.

Nakrem, H. A. 1989: Catalogue of fossils and geological material from Novaya Zemlya, U.S.S.R. Contributions from the Paleontological Museum, University of Oslo 356. $75 \mathrm{pp}$.

Nilsson, I. 1988: Carboniferous and Permian fusulinids on the Nordfjorden Block, Spitsbergen (Svalbard). Unpublished thesis, University of Oslo. 143 pp.

Ozawa. Y. 1925: Paleontological and stratigraphical studies on the Permo-Carboniferous limestone of Nagoto. P.2. Paleontology. Journal of the Collection Science, Tokyo Imperial University 45(6). $90 \mathrm{pp}$.

Rauzer-Chernousova, D. M. 1938: Verkhnepaleozoyskie Foraminifery Samarskoy Luki i Zavolzh'ya [The Upper Paleozoic foraminifera of the Samara Bend and the trans-Volga region]. Akademiya Nauk SSSR, Trudy Paleontologicheskogo Instituta 7, 69-167.

Rauzer-Chernousova, D. M., Belyaev, G. \& Reitlinger, E. 1936: Verkhnepaleozoyskic Foraminifery Pechorskogo Kraya [Upper Paleozoic Foraminifera from the Pechora Region]. Akademiya Nauk SSSR, Trudy polyarnoi komissii. vyp. $28,159-232$

Rauzer-Chernousova. D. M., Gryzlova, N. D., Kireeva, G. D., Leontovich, G. E., Safonova, T. P. \& Chernova, E. I. 1951. Srednekamernnougol'nye fusulinidy Russkoy Platformy i Sopredel'nykh Oblastey [Middle Carboniferous fusulinids of the Russian Platform and adjacent regions]. Akademiya Nauk SSSR, Institut Geologicheskikh Nauk, Ministerstuo Neftyana Promyshlennost SSSR. $380 \mathrm{pp}$.

Rozovskaya, S. E. 1963: Fusulinids from the Bükk Mountains, North Hungary. Geologica hungarica. Seria Paleontologica $28,3-43$.

Ross, C. A. \& Bamber, E. W. 1978: Middle Carboniferous and Early Permian fusulinaceans from Monkman Pass area, northeastern British Columbia. Geological Survey of Canada. Bulletin 267, 25-41.

Ross, C. A. \& Dunbar, C. O. 1962: Faunas and correlation of the Late Paleozoic Rocks of Northeast Greenland. Meddelelser om Gronland 167(5), 1-55.

Ross, C. A. \& Monger, J. W. H. 1978: Carboniferous and Permian Fusulinaceans from the Omineca Mountains, British Columbia. Geological Survey of Canada, Bulletin 267, 4355.

Semichatova, S. V., Einor, O. L., Kireeva, G. D., Gubareva, V. S., Grozdilova, L. P., Degtyarev, D. D., Lebedeva, N. S. \& Sinizina, Z. A. 1979. The Bashkirian stage in its type area of the Urals. Yorkshire Geological Society Occasional Paper 4, 83-98. 
Shul'ga-Nesterenko, M. I. 1955: Kamennoygolnye mshanki Russkoi Platformy [The Carboniferous bryozoans of the Russian Platform]. Akademiya Nauk SSSR, Trudy Paleontologicheskogo Instituta 57. 207 pp.

Utgaard, J. 1983: Systematic descriptions for the Order Cysto- porata. Pp. 358-439 in Boardman, R. S., Cheetham, A. H., Blake, D. L., Utgaard, J., Karklins, O. L., Cook, P. L., Sandberg, P. A., Lutaud, G. \& Wood, T. S. (eds.): Treatise on invertebrate paleontology, Part G, Bryozoa, Revised. Geological Society of America and University of Kansas. 